\title{
Elaborating Visual Narrative into Modern Adaptation Concept for Picture Book with Indonesian Folklore Theme
}

\author{
Dianing Ratri ${ }^{1,{ }^{*}}$ Riama Maslan Sihombing ${ }^{1,}$ Novita Elisa Fahmi ${ }^{1,}$ Refita Ika
}

Indrayati $^{2}$

\author{
${ }^{1}$ Institut Teknologi Bandung \\ ${ }^{2}$ Institut Teknologi Sumatera \\ ${ }^{*}$ Corresponding author.Email:dianing.ratri@itb.ac.id
}

\begin{abstract}
Folklore shows how a culture brings its point of view and values. It is also an agent of social values such as honesty, kindness, forgiveness, and many more. Through picture book, message from folklore can lead children understanding their society. These aspects are reasons why folklore becomes a favourite genre in picture book. Hence, some argue that folklore also store up cruelty and intimidating content which are not suitable for children. This leads creator and publisher to keep up with new way of adaptation. For example, by combining the method of modern storytelling technique and the art visual narration into the plot. The objective of this study is to design a new adaptation method for Indonesian folklore story by elaborating visual narrative into its story and illustration. By creating the formula, this study will not only help conserving Indonesian folklore stories, but also help delivering social values to children without the need of frighten the readers. This study follows a qualitative method by observing and existing Indonesian folklore books, which then categorized into three genres: Mythology, folktales, and fables. Samples from each category were then picked based on its popularity. A data collection of modern storytelling method and visual narrative literature were also done, which then mapped out into an adaptation concept suitable for children. The results show that visual narrative approach especially in visualizing characters and stage does help creating a modern stage of folklore adaptation. Adjustment of textvisual ratio along with plot simplification and reduction or removal of violence aspects also help creating a childfriendly folklore adaptation. Moreover, a picture book prototype was created to evaluate the result. It received positive response from The Asian Festival of Children's Content (AFCC) 2018 and London Book Fair 2019. Three of its illustration won awards from ASEAN Children's Book Illustrator (ICCRF) 2018.
\end{abstract}

Keywords: Folklore, picture book, modern adaptation, visual narrative, visual storytelling

\section{INTRODUCTION}

Folklore has always been a part of culture development, as it holds psychological and cultural significance through an elaboration between narratives, rituals and tradition encapsulated in experience and oral stories. Before, folktale has been cultivated slowly from time to time through oral tradition. When industrial revolution changes the world of literature with printing press technology, folktales found a new channel to evolved into literature [1] [2]. According to Zipes, folklore attracts its reader with the survival stories with hope. The plot provides us with alert of dangerous situation and lead us to helpful instruments or agents. This is because most of folktale story, despite the fantasy background, are like the world. Therefor it can be adjusted and transformed into different generation or readers. [2]. As good as the benefit of folklore in delivering moral, the problem with folklore is most of them were made during conservative era when patriarchy was dominant. This resulted in many stories promotes patriarchal, conservative gender roles, cruel punishment, and many others that are not suitable for children [2]. 
In Indonesia, folklore is one of long-lasting genre in children literature industry. Based on our observation, folklore can be found both in textbook (as part of literature study) and in picture book available in bookstore. Although it has been there for a long time, most of it are still presenting the same plot style following the original story, for example Cerita Rakyat Nusantara 4 by Tim Erlangga for Kids [3] which contains stories of Timun Mas, Malin Kundang, Putri Tandampalik, Cindelaras, Lutung Kasarung, and Pesan Istri Setia. Another example is Dayang Sumbi yang Pintar (Kisah Sangkuriang) [3] and Karena Tidak Mengakui Orangtua [4] (Malin Kundang) by Ali Muakhir. In these books, authors used original story that have inappropriate content for young readers, such as torment by parent, incest relationship, and patriarchy culture. Moreover, much research about folklore adaptation in children literature are still focusing more on how its value gives positive influence on children for their social life. We have difficulty to found how a modern adaptation can be made to adjust folklore in more modern social norm which are safe for young reader. Thus, there is a need to find an adaptation formula, to translate the origin story of Indonesian folklore, into a suitable picture book for children. Therefore, the objective of this research is to define and map out a modern adaptation concept for picture book with Indonesian folklore theme. There are two research problem that need to be solved: (1) What aspects should we consider in building new adaptation method for Indonesian folklore story, and (2) how to apply the new adaptation method in picture book for children.

\section{THEORY AND METHODS}

\subsection{Definition and Genres of Folklore}

According to Ben-Amos [5], definitions of folklore are as many and varied as the versions of a well-known tale. it conveys tradition, ancient customs, old ditties and dateless ballads, archaic myths, legends and fables, and timeless tales and proverbs. Folklore was also considered as an expression of man for his surroundings. In traditional definition of folklore, traditionalism, irrationality, and rurality, dominated the concept of folklore. It can be a story or narrative, songs or a combination of myths, legends, music into one story [5].

Since one of folklore feature is it never have an author [6], it was performed repeatedly by different peoples on various occasions. Therefore, the talent of the teller, the moment of recitations, and the response of the audience may all effect the text of folklore's tale or song. In conclusion, folklore can be one of these three: a body of knowledge possessed by one community or society, a collective representation of thought, and a communal creation or re-creation art [5]. In short, it can be defined as "the rituals, songs, stories, legends, and popular practices handed down orally from one person to another, rather than through written transmission [7].

Folklore can be categorized by different approaches such as by thematic approach, holistic approach, archetypal approach, and functional approach [5]. For this paper we will divide the genre based thematic approach, which suites best for children literature. Previous literature had classified Folklore into many genres. For example, in his book, "Morphology of the Folktales", Proop et. al. mentioned different classification, such as from Miller: (1) fantastic content; (2) tales of everyday life; (3) and animal tales, classification by Wundt: (1) mythological tale-fables; (2) pure fairy tales; (3) biological tales and fables; (4) pure animal fables; (6) joke tales and fables ; (7) moral fables, classification by Vólkov: (1) animal tales, (2) tales proper, (3) anecdotes [8]. Rosenberg and Brown shortlists five most common genres as: (1) fairy tales; (2) legends, (3) myths, (4) tall tales, and (5) fables [7]. Meanwhile, Ben-Amose, Glassie, and Oring classify three genres: (1) Legends; (2) Märchen or Myth; (3) Fables; and (4) Proverbs that encapsulate traditional wisdom p.41 [5].

Based on our observation, only few of those genres are applicable to samples of Indonesian folklore titles. Therefore, we refine the category into three genres:

a) Myth. A traditional story, which involve supernatural beings or forces and provides an explanation or justification for something such as the early history of a society, a religious belief or ritual, or a natural phenomenon [9].

b) Legend. A traditional story which tells about a particular person or place. Formerly, the term legend meant a tale about a saint. Legends resemble folktales in content; they may include supernatural beings, elements of mythology, or explanations of natural phenomena, but they are associated with a particular locality or person and are told as a matter of history[10].

c) Folktales (including tales of everyday life, fairy tales and fables). These kinds of story include tales that considered as a fiction of everyday life, more casual than myth and legend, yet are still containing a moral or 
social norms as its message. While the protagonist of folktale is usually a commoner or mortals, some of them are still include magical creature such as fairies and animals that behave and speak as human [11].

\subsection{Visual Narrative in Picture Book}

\subsubsection{The Correlation between Picture and Text}

Headings In a picture book, Text and illustration sequence would complete each other. They have a synergistic relationship in which the total effect depends not only on the union of the text and illustrations but also on the perceived interactions or transactions between these two parts [12].

Reader's construction of the relationship between text and pictures is one of the affordances of picture books, with a constant alternation between imagemaking and word-making. As we alternate our attention between words and pictures in a picture book, then, we may be representing the verbal and nonverbal information in separate cognitive structures; following this, through the complex referential connections between these two cognitive structures, we construct an integrated meaning [12].

In his book, Nodelman[13] said that the connection between children with pictures in picture book has been there since the trend of brightly colored pictures developed in Europe and America during nineteenth century. This is because picture are concentrated versions of aspects of physical reality, consist in color, texture, shape, and line. Thus, illustration does not only attract and hold children's interest toward the book, but it will also help them to clarify and learning the words, and subject after, inside the book. However, as picture can depict more than one meaning, the most important context provided for the picture in picture book is text, which will influence our understanding of the picture [13]. In picture book, picture is not only repeat the meaning of text, but it can also make deeper story meaning, even contradict the text and enrich or twist the story [14]. Text and pictures have a combative relationship as well as completing each other by virtue their differences. This can happen because text and picture can communicate different kinds of information while working together by limiting each other's meaning. As the result, the relationships between pictures and texts in picture books tend to be ironic: each speaks about matters on which the other is silent. That is why it is important to create illustration which not only function as decoration, but also as an element that can tells its own story.

\subsubsection{Gestures \& Expression}

Children respond to character gestures to understand picture, also how they act in with their surroundings. Moreover, shapes and textures of object can make us pay attention to see another object in the picture. For example, an image that comes to a point tends to grab our attention less on itself than on what it points toward, no matter how big it is or what surrounds it. Sometimes contrast in shapes also make smaller image stand out more than bigger object next to it. It also applied to the absence of background, which give reader more attention on the action of the characters rather than on their relationship to their setting [13] [15].

\subsubsection{Three-dimensional scenes in two- dimensional space}

As visual representation, the two-dimensional space of paper surface could become a threedimensional space, or the space of the scene depicted. By applying different layer in the scenes, picture book can give different weight and significance to different parts of pictures. These techniques can be achieved by creating illusion of lightings, placement of characters, and vary camera angles, which can attract attention to certain aspects of what an audience sees on the stage. For example, to make the character important, it can be placed either in the foreground. In contrary, picture placed in the background, tend to have the meaning of hidden, forgotten or even creating a certain mood of negative emotion. Emotion and mood can also be achieved by manipulating lighting aspect. A tense scene for example, can be created by a contrast of darker and lighter light side by side [13], [14].

\subsubsection{Themes in Picture Book}

Picture book has diverse themes ranging from fairytales to difficult subject like death, illness, abuse, and racism. These themes have been stayed under the shadow for many years since many commentators especially adult, believe that young readers must be protected from all things unpleasant and dangerous, including from those in literature [14]. In opposite, writers and illustrator consider that this subject is also important, especially for children with unusual or difficult situation. With a simpler words and visual metaphor, picture book can help children understand difficult subject above. The question is how to soften 
sensitive subject such as cruel torture, punishment, and dooms which can be too horrifying for young reader.

\subsubsection{Book's reading level according age groups}

Reading level were created to match the content inside the book with their reader's reading ability.
According to Room to Read Accelerator Project in their writer and illustrator workshop [16], there are seven criteria to determine reading level for children: (1) word and sentence complexity, (2) number of sentences per page, (3) number of words per sentence, (4) suitable topics, (5) illustration percentage, (6) editing pattern, and (7) number of pages with layout and size pattern. The complete guidance can be seen in Figure 1.

\begin{tabular}{|c|c|c|c|c|c|c|c|}
\hline Level & $\begin{array}{l}\text { Word and } \\
\text { sentence } \\
\text { complexity }\end{array}$ & $\begin{array}{l}\text { Sentence } \\
\text { per page }\end{array}$ & $\begin{array}{c}\text { Words } \\
\text { per } \\
\text { sentence }\end{array}$ & Suitable topic & Illustration & Editing Pattern & Layout \\
\hline 1 & $\begin{array}{l}\text { Very simple } \\
\text { Singular word } \\
\text { Phrase }\end{array}$ & $0-1$ & $1-3$ & $\begin{array}{l}\text { - Simple and familiar topic } \\
\text { - Storylines are not really } \\
\text { raised } \\
\text { - Label for familiar image, } \\
\text { object, and action }\end{array}$ & $\begin{array}{l}\text { - } \quad<90 \% \text { of the page } \\
\text { - Provide strong support } \\
\text { for text } \\
\text { - Simple and clear }\end{array}$ &  & $\begin{array}{l}\text { - } 8-12 \text { pages } \\
\text { - } \text { Big size } \\
\text { - } \quad \text { Consistent text } \\
\text { placement } \\
\text { - } 1 \text { text line per page }\end{array}$ \\
\hline 2 & $\begin{array}{l}\text { Simple } \\
\text { sentence and } \\
\text { punctuation } \\
\text { (.) } \\
\text { Sentence are } \\
\text { always } \\
\text { completed }\end{array}$ & $1-3$ & $1-5$ & $\begin{array}{l}\text { - } \text { Basic concept } \\
\text { - } \text { Familiar situation } \\
\text { - Storylines are not really } \\
\text { raised } \\
\text { - Likeable topic can be } \\
\text { given }\end{array}$ & $\begin{array}{l}\text { - } \quad<80 \% \text { of the page } \\
\text { - Explicitly support text } \\
\text { meaning. }\end{array}$ & $\begin{array}{l}\text { - Provide pattern and } \\
\text { repetition } \\
\text { - Basic words increase in } \\
\text { amount } \\
\text { - Text are predictable } \\
\text { - Avoid words with } \\
\text { abstract definition }\end{array}$ & $\begin{array}{ll} & 12-16 \text { pages } \\
\text { - } & \text { Big size } \\
\text { - } & \text { Consistent text } \\
& \text { placement } \\
\text { - } & 1-3 \text { text line/page }\end{array}$ \\
\hline 3 & $\begin{array}{l}\text { Simple } \\
\text { sentence, but } \\
\text { longer length } \\
\text { More } \\
\text { punctuation } \\
\text { marks (. , ?) } \\
\end{array}$ & $2-5$ & $3-8$ & $\begin{array}{l}\text { - Familiar and unfamiliar } \\
\text { concept are welcome } \\
\text { - Simple storyline } \\
\text { appeared } \\
\text { - Likeable topic can be } \\
\text { given } \\
\end{array}$ & $\begin{array}{l}\text { - }<80 \% \text { of the page } \\
\text { - Support text meaning } \\
\text { but not too obvious }\end{array}$ & $\begin{array}{ll}\text { - Introduction of } \\
\text { unfamiliar words and } \\
\text { decodable words. } \\
\text { - Introduction of dialog }\end{array}$ & $\begin{array}{l}\text { - } 12-24 \text { pages } \\
\text { - } \text { Big size } \\
\text { - } \quad \text { Flexible text placement, } \\
\text { but still within the same } \\
\text { line. } \\
\text { - } 2-4 \text { text line/page }\end{array}$ \\
\hline 4 & $\begin{array}{l}\text { Words and } \\
\text { sentences } \\
\text { structure are } \\
\text { more complex }\end{array}$ & $3-6$ & $6-10$ & $\begin{array}{l}\text { - Theme and genre are } \\
\text { broader } \\
\text { - Introduction of complex } \\
\text { concept }\end{array}$ & $\begin{array}{l}\text { - } \quad<70 \% \text { of the page } \\
\text { The role of illustration in } \\
\text { giving clue and text } \\
\text { meaning are reduced }\end{array}$ & $\begin{array}{l}\text { - Text bubble can be used } \\
\text { - Repetition of new } \\
\text { words }\end{array}$ & $\begin{array}{l}\text { - } 16-32 \text { pages } \\
\text { - Portrait format can be } \\
\text { used } \\
\text { - } \text { Design aspect are more } \\
\text { details, especially in } \\
\text { font type and layout. } \\
\text { - } 3-5 \text { text lines/pages }\end{array}$ \\
\hline 5 & $\begin{array}{l}\text { Complex } \\
\text { sentences and } \\
\text { paragraph can } \\
\text { be used }\end{array}$ & $4-8$ & $7-15$ & $\begin{array}{l}\text { - Complex plot with } \\
\text { many/ continuing plot } \\
\text { - Twist inside story } \\
\text { - Introduction of } \\
\text { metaphor }\end{array}$ & $\begin{array}{l}-\quad<60 \% \text { of the page } \\
\text { - The role of illustration in } \\
\text { giving clue and text } \\
\text { meaning are reduced }\end{array}$ & $\begin{array}{ll}\text { - } & \text { New words are } \\
\text { increased } \\
\text { - } \\
\text { There are not many } \\
\text { repetition } \\
\text { - } \begin{array}{l}\text { Dialog between } \\
\text { characters }\end{array} \\
\end{array}$ & $\begin{array}{l}\text { - } 20-48 \text { pages } \\
\text { - } \quad \text { Portrait format } \\
\text { - } \text { Maximum } 10 \text { text } \\
\text { line/pages }\end{array}$ \\
\hline 6 & $\begin{array}{l}\text { Words, } \\
\text { sentences, } \\
\text { punctuations, } \\
\text { and language } \\
\text { are varied and } \\
\text { complex }\end{array}$ & $\begin{array}{l}\text { Text can } \\
\text { be } \\
\text { applied } \\
\text { in full } \\
\text { pages. }\end{array}$ & - & $\begin{array}{l}\text { - No limitation in theme } \\
\text { as long as it suitable for } \\
\text { children }\end{array}$ & $\begin{array}{l}\text { - Illustration is not } \\
\text { mandatory }\end{array}$ & - & - \\
\hline
\end{tabular}

Figure 1 Reading Level guidance for children by Room to Read

\subsection{Design Method}

Based on literatures above, we can conclude few recommendations to build new approach for Indonesian folklore adaptation in picture book:

1. Reducing folklore's genres into three types: myth, legends, and folktale.

2. Using reading level guidance level 4 (see Figure 1) as the guideline to simplify plot, stories, and manage number of sentences per page. By selecting this level, not only it will allow us to have broader theme and genre, which are suitable for folklore adaptation. This level will also help us in adjusting textvisual ratio according to age groups and help us in removing negative aspect from the original story.

3. Applying visual narrative approach as storytelling, which include gesture and expression and creation of three-dimensional scenes as background.

To collect and pick right stories, we used folklores listed by Language and Book Development Agency (Badan Pengembangan dan Pembinaan Bahasa) under 
Indonesian Ministry of Education and Culture [17]. This decision was made to ensure that folklores that we choose were original and curated by its expertise. (Note: The Ministry of Education and Culture had updated their website. Folklore and other stories are now can be found in their newest platform: Buku Digital [18]. The next step is to select folklores with suitable themes for children with reading level 4, which age $8-9$ years old. We eliminated themes with sensitive issue that are not suitable for children such as marriage between family members, patriarchy and unfair gender role, cruelty, and gruesome punishment. Instead, we focus to titles that introduce and celebrate friendship, honesty, loyalty, kindness, and other positive morale and social value

16 weeks of illustration and story workshop was held to create the prototype, with two professional editors from PT. Elex Media Komputindo (our partner of Indonesian book publisher) added to the team as curator. Our goal is to simplify the plot into: introduction, conflict development, climax and resolution with a modification of plot, characters, and settings if needed. The whole design process can be seen as below in Figure 2.

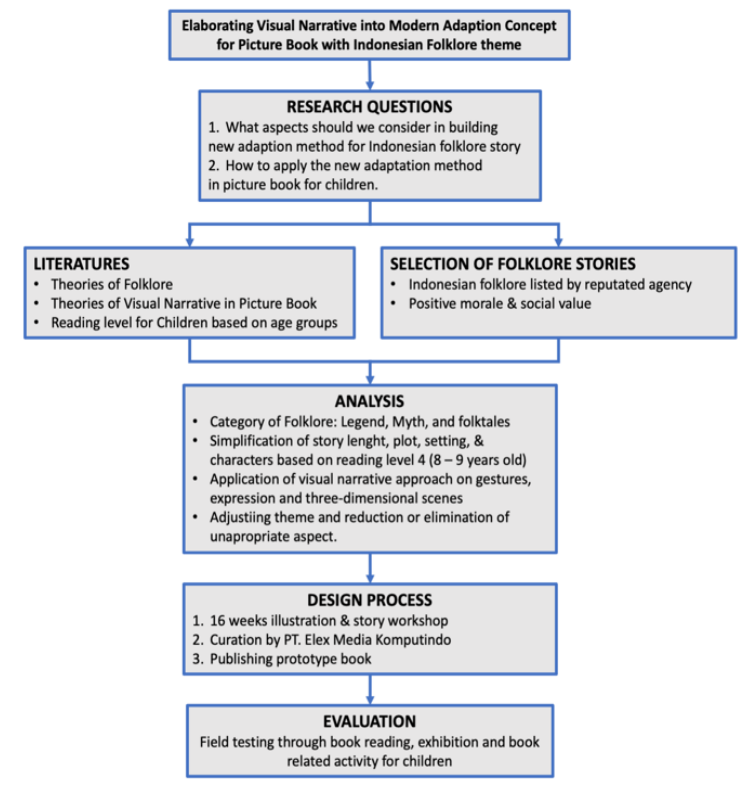

Figure 2 Design Process

\section{RESULT}

\subsection{Creating New Adaptation Book}

After samples were collected, research team held 16 weeks workshop for creators to develop their story and illustration. In each of weekly session, creators were given theories of folklore, adaptation, and picture book illustration, including story, plot, and character development, creating setting, lighting, and mood, also picture book design and typography. Creators were also introduced to various reading level according to age groups and how to adjust their story into each of age groups. During this workshop, creators were accompanied by mentors from research team, and editor from PT. Elex Media Computindo. From this workshop, we produced around 28 illustrated story (figure 3), which then curated by research teams, editors, and expertise from Illustration community into 14 selected stories. Titles are: Kisah Kera dan Bangau (The story of Monkey and Stork), Lutung Kasarung (The Legend of Lutung Kasarung), Kekekow (Tale of Kekekow Bird), Batara Kala (Myth of Batara Kala), Kina (The origin of Kina), Ni Pohaci (Tale of Ni Pohaci), Kisah Penyumpit and Putri Malam (Tale of Blowgun man and Night princess), Kisah Kera dan Kura-Kura (Tale of Monkey and Turtle), Sipiso Somalim (Tale of Sipiso Somalim), Bawang Merah dan Bawang putih (Tale of shallot and garlic), Tongkat Permata (Legend of Kapal Island), Legenda Putri Hijau (Legend of Green Princess), Nasi Tumpeng Setinggi Bukit Catu (The tale of Tumpeng Rice from Bukit Catu), and Watuwe, si Buaya Ajaib (Legend of Watuwe, the magical Crocodile).

In all selected stories, methods that we coded before were applied. For example, most characters despite of their age, were drawn with a proportion of children. Those who were not was given various if not exaggerating expression and gestures that children can understand easily.

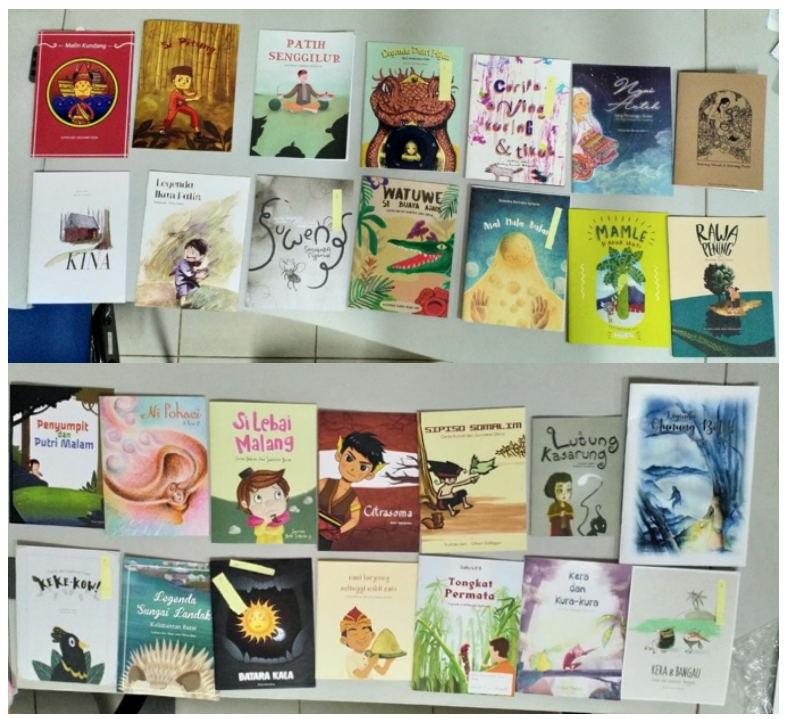

Figure 3 Mockups of Folklore Adaptation stories produced by creators

A simplified plot with elimination of cruel punishment was also applied. For example, in Legend of Lutung Kasarung, the plot was focused on how 
Princess Purbasari revived her right as a queen with the help of her best friend, Lutung Kasarung. In the end of Myth of Batara Kala, instead of being decapitated, Batara Kala's head became bigger and bigger while his body became smaller before completely disappeared. In the tale of Kekekow Bird, the bird was died from exhaustion as its keep granting the villagers' request. This plot was adjusted with the story tells how Kekekow Bird went away from villagers and never come again.

\subsection{Public Receptions}

The prototype book was titled "Rangkaian Andara Nusantara: 14 Adaptasi Cerita Rakyat Nusantara" (Rangkaian Andara Nusantara: 14 folklore adaptations from Nusantara". This book was showcased at The Asian Festival of Children's Content (AFCC) 2018 at National Library Building, Singapore from September $5^{\text {th }}$ to $8^{\text {th }}, 2018$ (Figure 4). Aside from book showcase, research team were also observed the reception of local and international visitors toward the book. Most of visitors who show interest in this book were parents who are also Indonesian living in Singapore, and Malayan. Many of them hoped that this book can become another option of folklore stories from Indonesia, as there are only few in Singapore. As for the story aspect, we found that visitor enjoy the story and had no objection toward the simplification of the plot nor adjustment in some aspects including character development and refined story.

Artwork from the book were also exhibit at The International Children's Content Rights Fair (ICCRF) 2018 in Chiang Mai, Thailand from November $29^{\text {th }}$ to December $2^{\text {nd }} 2018$. Three of the creators received "Rising Star Award" of The ASEAN Children's Book Illustrator Award at ICCRF for their folklore illustration, indicating that the adaptation method we brought through illustration was well accepted by expertise in illustration industry.

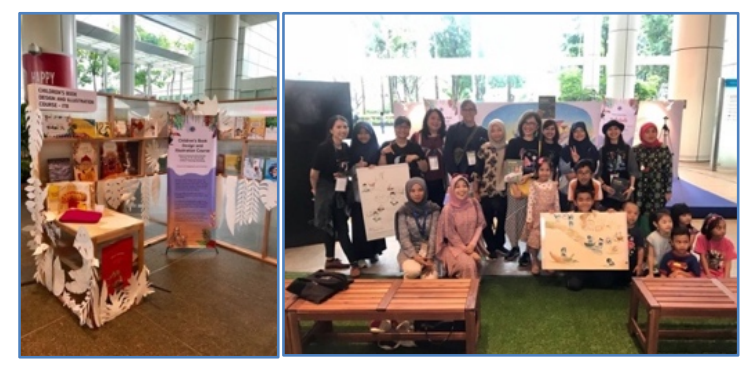

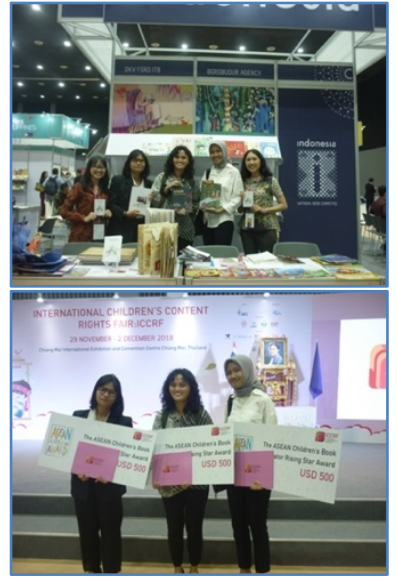

Figure 4 Documentation from showcase event at The Asian Festival of Children's Content (AFCC) 2018 and The International Children's Content Rights Fair (ICCRF) 2018

The book was published on March 18, 2019, by PT. Elex Media Komputindo and since were distributed in national wide. The book was also showcased at London Book Fringe Program as one of highlight of Indonesia as the Market Focus Country at the 2019 London Book Fair at Olympia in Kensington, March 12-14, 2019. In this event, our team organized an exhibition of five stories from the book, with read aloud and children workshop activity (figure 6). In the workshop, children created a mask from "The Legend of Watuwe the Magic Crocodile", made a "Tie", a traditional headband from "The Tale of Sipiso Somalim", participated in a drawing activity and made a cone rice paper craft of yellow rice from "The Tale of Tumpeng Rice from Bukit Catu". Through this workshop activity, children can understand more of the story in the book as it gives connection through similarity and differences between their culture and culture in the book. For example, while learning about Indonesian yellow rice, children can relate with what kind of food they have in their culture, making connection of traditional costume and accessories through mask and tie making. 


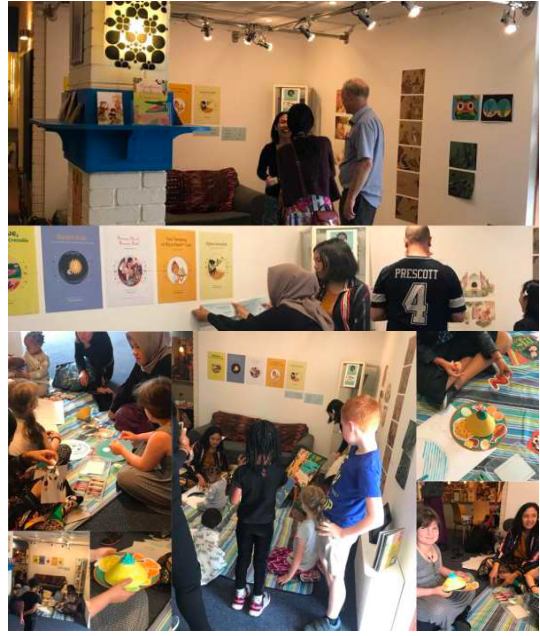

Figure 5 Exhibition and workshop activity at Bedford, United Kingdom

\section{DISCUSSION \& CONCLUSIONS}

Folklore has been one of a method to learn about one's culture. Through time, the spreading of folklore evolved from oral stories to printed books. While the moral stories are long lasting and can be adapted into newer age, some of its element might not be suitable anymore, especially for children. Thus, adaptation method should be created to bring a new version of child friendly folklore. Through analysis this research found that here are ways to bring folklore adaptation as child friendly as possible. Inappropriate element such as cruel punishment, gender issue, and other conservative norm that promote inequality can be eliminated without reducing positive message and essence of its original story. To fulfil this, we borrowed methods from visual narrative and theory of picture book. There are five aspects that we considered in creating modern adaptation of Indonesian folklore for children:

1. Creating a character that can connect easily with children. This can be done by emphasizing their gesture and facial expression so it can help explaining the plot and story, especially for more complex folklores.

2. Another visual narrative method that we applied was by creating an illusion of threedimensional stage in each scene. This can be made by placing character and other visual element in arrangement of foreground, middle ground, and background in adjusting to story and mood.

3. Simplifying plot and story according to children reading level. This include adjusting numbers of text and the proportion between text and illustration.

4. Reduction, removal or replacement of violence and inappropriate aspects with things that are suitable for children.

5. We also found that aside from visual and text aspect in the book, we can also use creative activity related to the folklore to bring more connection with the readers.

This research was an experiment on creating folklore adaptation method through visual narrative approach. The analysis was translated into prototype book, which was tested through exhibition and publishment. We found that readers were excited to read the book, and there were no complains in the changes that have been made. This can indicate that methods we made were accepted by readers. Aside from the public reception, the validation process can be continued by conducting a comparison experiment between the prototype and the original folklore stories. By conducting this, we hope we can improve the validation of the result.

\section{ACKNOWLEDGMENTS}

The research was supported by Program Penelitian, Pengabdian kepada Masyarakat dan Inovasi (P3MI) 2018 of Institut Teknologi Bandung (ITB) with a collaboration with PT. Elex Media Komputindo as Publishing partner. Any opinions, findings, and conclusions or recommendations expressed in this paper are those of the authors and do not necessarily reflect both P3MI program, ITB and PT. Elex Media Komputindo.

\section{REFERENCES}

[1] A. Dundes, S.J. Bronner, The Meaning of Folklore: The Analytical Essays of Alan Dundes, Utah State University, 2007.

[2] J. Zipes, Why fairy tales stick: the evolution and relevance of a genre, Routledge, 2006.

[3] A. Muakhir, Dayang Sumbi yang Pintar (Kisah Sangkuriang), Jakarta, Serambi Ilmu Semesta, 2017.

[4] A. Muakhir, Karena Tidak Mengakui Orangtua, Jakarta, Serambi Ilmu Semesta, 2017. 
[5] D. Ben-Amos, H. Glassie, E. Oring, Folklore concepts: histories and critiques, 1st ed, Indiana University Press, 2020.

[6] V. Propp, Theory and History of Folklore, 4th ed, Minneapolis: University of Minnesota Press, 1984.

[7] B.A. Rosenberg, M.E. Brown, Encyclopedia of folklore and literature, ABC-CLIO, 1998.

[8] V. Propp, S. Pírková-Jakobsonová, L. Scott, Morphology of the folktale, Martino Fine Books, 2015.

[9] Myth, n.d. Available from: www.oed.com/view/Entry/124670 (accessed July 26, 2021).

[10] Legends | Definition of Legends by MerriamWebster, n.d. Available from: https://www.merriamwebster.com/dictionary/Legends (accessed July 26, 2021).

[11] Fable | literature | Britannica, n.d. Available from: https://www.britannica.com/art/fable (accessed July 26, 2021).

[12] L.R. Sipe, How Picture Books Work: A Semiotically Framed Theory of Text-Picture Relationships, Children's Literature in Education 1998, 29:2, 1998, pp. 97-108. DOI: https://doi.org/10.1023/A:1022459009182.

[13] P. Nodelman, Words about pictures: the narrative art of children's picture books, 1st ed, University of Georgia Press, 2013.

[14] M. Salisbury, M. Styles, Children's picturebooks: the art of visual storytelling, 2012.

[15] M. Bang M, Picture this: how pictures work, 2016.

[16] Room to Read Accelerator Project, 2018.

[17] Daftar Cerita Anak | Badan Pengembangan dan Pembinaan Bahasa, Kementerian Pendidikan dan Kebudayaan, n.d. Available from: http://badanbahasa.kemdikbud.go.id/lamanbaha sa/jenis_produk/cerita\%20anak (accessed August 27, 2021).

[18] Buku Digital - Badan Pengembangan dan Pembinaan Bahasa, n.d. Available from: https://budi.kemdikbud.go.id/ (accessed August 28, 2021). 